\title{
急冷凝固した $\mathrm{Al}-4$ mass\% $\mathrm{Cu}-\mathrm{Cr}$ 合金の時効現象 ${ }^{*}$
}

\author{
鈴木 寿** ・ 伊藤 吾朗** 小山 克己***
}

Aging phenomena of rapidly solidified Al-4mass $\% \mathrm{Cu}-\mathrm{Cr}$ alloys*

UDC : 669. 715'3'26-14:621.785.7

\author{
Hisashi SUZUKI**, Goroh ITOH** \\ and Katsumi KOYAMA***
}

The Al-4mass $\% \mathrm{Cu}-(0 \sim 4.5)$ mass $\% \mathrm{Cr}$ alloys were prepared by chill-casting, and their heat-resisting properties were examined. The amount of solute $\mathrm{Cr}$ quenched in $\mathrm{Al}-4 \% \mathrm{Cu}$ alloy was about $1.5 \%$ at maximum. Resistance to over-aging was markedly increased with increasing amount of solute $\mathrm{Cr}$, when the alloys were subjected to usual heat-treatments: that is, homogenization at $793 \mathrm{~K}$ after chill-casting, water-quenching, aging at $473 \mathrm{~K}$ and subsequent over-aging at $623 \mathrm{~K}$. This phenomenon would mainly be attributed to the fact that $\theta^{\prime}$ formed during pre-aging became very stable both in the amount and the size, as the amount of solute $\mathrm{Cr}$ increased. The chill-cast $\mathrm{Al}-4 \% \mathrm{Cu}-2 \% \mathrm{Cr}$ alloy was thought to be superior to commercial heat-resisting 2219 alloy. The over-aged structures of $\mathrm{Cr}$ contained alloys were in detail discussed, in comparison with those of $\mathrm{Mn}$ contained alloys.

(Received December 5, 1983)

\section{1. 緒言}

著者らの既報の結果 ${ }^{1)}{ }^{2}$ ) によると，急冷凝固（チル・ キャスト）法によつて Mn を強制固溶させた Al-4 mass $\% \mathrm{Cu}-(0 \sim 4)$ mass $\% \mathrm{Mn}$ 合金は, 高 $\mathrm{Mn}$ 合金ほど過時 効処理時にMn を含む中閒相 $\left(\mathrm{T}^{\prime}\right)$ が高密度に生じ，しか も $\mathrm{T}^{\prime}$ が粗大化しにくいために, 過時効軟化が抑えられ ることが分つた。すなわち高 Mn 合金ほど耐熱性が優れ ると判断された。

ところで $\mathrm{T}^{\prime}$ の粗大化が抑えられたのは $\mathrm{Mn}$ 原子のア ルミニウム中での拡散係数 $\left(\mathrm{D}_{\mathrm{Mn}}\right)$ が小さいためと考え

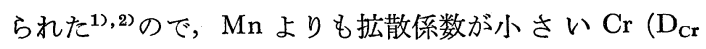
は $\mathrm{D}_{\mathrm{Mn}}$ の約 $\left.1 / 100\right)^{3}$ に着目すると, $\mathrm{Al}-\mathrm{Cu}-\mathrm{Cr}$ 合金は興 味ある性質を示すと思われた。これに関連し，最近は耐 熱性アルミニウム合金が核融合炉の炉壁材料として注目

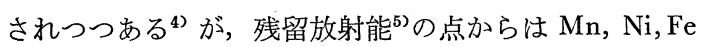
などを添加した現用の耐熱性アルミニウム合金よりも Cr 添加合金の方が好都合と思われる。以上により，ここ では $\mathrm{Cr}$ を強制固溶させた $\mathrm{Al}-4$ mass $\% \mathrm{Cu}$ - ( $0 \sim 4.5)$ mass $\% \mathrm{Cr}$ 合金の耐熱性を基礎的に調べることにし，過
時効段階における時効現象を主として検討した。いうま でもなくここよらな研究はまだ見られていない。

\section{2. 試料および実験方法}

高純度素材を用いて Al-4mass \% Cu- ( 0 〜 4.5) mass \% $\mathrm{Cr}$ 合金を大気中で溶解し， $30 \times 60 \times 160 \mathrm{~mm}$ の金型に 鋳造した。各鋳塊の分析值は Table 1 に示す通りであ る。次にこれら鋳塊を再溶解し, 溶湯を $1173 \mathrm{~K} に$ 保持し た後, 銅鋳型 (型温, $273 \mathrm{~K}$ ) にチル・キャスドして $1.5 \mathrm{~mm}$ 厚の板状試片を得た。この試片を $793 \mathrm{~K} て ゙ 0.6$ ks 均質化処理, 水焼入れ後, $473 \mathrm{~K}$ で時効し, 続いて $623 \mathrm{~K}$ で過時効処理を行い，これに伴ら硬さ( $\mathrm{Hv}$ ，荷重 $4.9 \mathrm{~N}$ ) および組織変化を追求した。得られた結果を既報1),2)の $\mathrm{Al}-\mathrm{Cu}-\mathrm{Mn}$ 合金の結果と比較し, $\mathrm{Cr}$ と $\mathrm{Mn}$ の差につい ても，明確にしようとした。

\section{3. 実験結果および考察}

Photo 1 はチル・キャスト試片の光顕組織であるが, いずれの合金にも $\alpha$ 相がデンドライト状に生じ，最終凝 固部であるデンドライト・セル境界には他相を生じてい

* 日本金属学会第93回秋期大会 (58-10) にて発表した。

** 東京大学工学部 (東京都)。Faculty of Engineering, The University of Tokyo (Tokyo).

*** 東京大学大学院 (東京都)。Graduate School, The University of Tokyo (Tokyo). 
Table 1 Chemical composition of specimens. (mass \%)

\begin{tabular}{rlr}
\hline \multicolumn{1}{c}{ Alloys } & $\mathrm{Cu}$ & $\mathrm{Cr}$ \\
\hline $0 \% \mathrm{Cr}$ & 3.85 & - \\
$1 \% \mathrm{Cr}$ & 3.93 & 0.81 \\
$2 \% \mathrm{Cr}$ & 3.86 & 1.86 \\
$4.5 \% \mathrm{Cr}$ & 3.69 & 4.54 \\
\hline
\end{tabular}

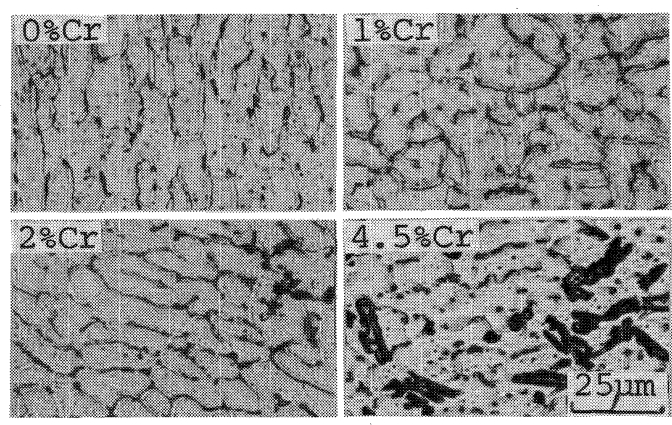

Photo 1 Optical micrographs of $\mathrm{Al}-4 \% \mathrm{Cu}-(0 \sim$ $4.5) \% \mathrm{Cr}$ alloy specimens, chill-cast in a copper mold with $1.5 \mathrm{~mm}$ thickness.

る。 $2 \% \mathrm{Cr}$ 以上の合金には，黒色に食刻される 粗大化 合物が生じており，その量は高 $\mathrm{Cr}$ 合金ほど多くな る。Table 2 はX線回折により各試片に生じた化合物を 同定した結果である。これより最終凝固部に 生じた他 相は準安定相（構造不明， $\mathrm{X}_{1}$ と呼称）または安定相 $\theta$ $\left(\mathrm{CuAl}_{2}\right)$ であり，黒色の粗大相は準安定相（構造不明,

$\mathrm{X}_{2}$ と呼称）または $\mathrm{CrAl}_{7}$ であることが分つた。次に試 片の比抵抗拉よび母相の格子定数を測定し，母相中への $\mathrm{Cr}$ 固溶量を見積つた ${ }^{6), 7)}$ 結果*, $1 \% \mathrm{Cr}$ 合金では添加 $\mathrm{Cr}$ 量の約 $100 \%$ が，2\% Cr 合金では約 $77 \%$ が母相中に固溶 するど見なされた $(\mathrm{Cu}$ 固溶量はいずれも添加量の 45 \%)。しかし $4.5 \% \mathrm{Cr}$ 合金では約 $16 \%$ となり，固溶量が 減少した $(\mathrm{Cu}$ 固溶量, 約 $14 \%)$ 。これは主として $\mathrm{CrAl}_{7}$ が生成するためと思われた。よつて以下の研究は $2 \% \mathrm{Cr}$ 合金を主対象に行うこととした（比較試料は $2 \% \mathrm{Mn}$ 合 金) が，Mn 添加合金では最大約 $4 \% \mathrm{Mn}$ の強制固 溶が 可能であった1)ことを考えると，Cr と Mn とではかな り事情が異なつている。

次に Fig. 1 には $2 \% \mathrm{Cr}$ 合金について，鋳造状態抒 よび793K で $0.6 \mathrm{ks}$ 焼鈍（均質化）後の $\mathrm{Cu}$ および Cr濃 度の分布をデンドライト・セル境界からの距離の関係で

* $\mathrm{Al}-\mathrm{Cu}$ 抢よび $\mathrm{Al}-\mathrm{Cr} 2$ 元合金についての固溶量と格 子定数6)，固溶量と比抵抗 ${ }^{7)}$ の関係を用い， 3 元合 金においては格子定数も比抵抗も，2種の溶質濃度 に対する值の単純和になると仮定して求めた。この 結果は Photo 1 や Table 2 の結果と矛盾しない。
Table 2 Compounds appearing in chill-cast specimens, determined by X-ray diffraction method. Refer to Photo 1.

\begin{tabular}{|c|c|}
\hline Alloys & Compound \\
\hline $0 \% \mathrm{Cr}$ & metastable phase $\left(\mathrm{X}_{1}\right)$ \\
\hline $1 \% \mathrm{Cr}$ & $\mathrm{X}_{1}+\theta$ \\
\hline $2 \% \mathrm{Cr}$ & $\mathrm{X}_{1}+\theta+$ metastable phase $\left(\mathrm{X}_{2}\right)$ \\
\hline $4.5 \% \mathrm{Cr}$ & $\theta+\mathrm{CrAl}_{7}+\mathrm{X}_{2}$ \\
\hline
\end{tabular}

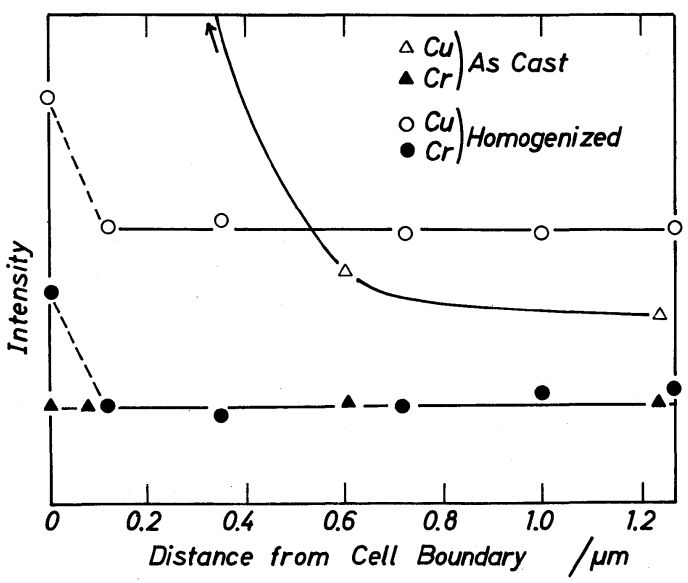

Fig. 1 Results of EDXS point analyses on $2 \% \mathrm{Cr}$ alloy specimens of as chill-cast and homogenized (at $793 \mathrm{~K}$ for $0.6 \mathrm{ks}$ ) states, as a function of distance from a cell boundary.

示した (EDXS 分析による)。鋳造状態で Cr はほぼ均 一に分布するが， $\mathrm{Cu}$ はセル境界の近傍に著しく偏析し ている。しかし793Kで0.6 ks の焼鈍を行うと，Cu 濃度 はセル境界以外ではほぼ均一となるが，Cr はセル 境界 上に偏析するようになる。 $2 \% \mathrm{Cr}$ 合金の均質化焼 鈍 後 のセル境界付近の TEM 組織をPhoto 2 亿示す $(2 \%$ Mn 合金の組織を併示）が，いずれの合金にもセル境界 上に析出相が見られる。しかし $2 \% \mathrm{Cr}$ 合金の方がその 寸法は小さく, 析出量も少ない。Photo 2 には析出相の 電子線回折図も示したが，これによれば $2 \% \mathrm{Cr}$ 合金に 生じる析出相は, $2 \% \mathrm{Mn}$ 合金に生じる析出相 ( $\mathrm{T}$ 相: $\mathrm{Cu}_{2}$ $\left.\mathrm{Mn}_{3} \mathrm{Al}_{20}\right)^{1)}$ と類似の構造を有することが分る。他の方位 から電子線を入射させた場合も同様の結果が得られた。 $\mathrm{Al}-\mathrm{Cu}-\mathrm{Cr}$ 系合金においては状態図的には 3 元化合物 が存在しないとされる ${ }^{8)}$ が，上記結果と Fig. 1の結果よ り, $2 \% \mathrm{Cr}$ 合金に生じた析出相は $\mathrm{Cu}_{2} \mathrm{Cr}_{3} \mathrm{Al}_{20}$ に近いも のとなる (以下 $\mathrm{Cu}_{2} \mathrm{Cr}_{3} \mathrm{Al}_{20}$ と仮称)。そうすると $\mathrm{Cr}$ 添 加合金の方が析出量が少なかつたので，母相中の $\mathrm{Cu}$ ， $\mathrm{Cr}$ 固溶量は $\mathrm{Mn}$ 添加合金の $\mathrm{Cu}, \mathrm{Mn}$ 固溶量よりも多い ことになる。2 $\% \mathrm{Cr}$ 合金を $\mathrm{X}$ 線回折によつて調べたと ころ, 鋳造状態で生じていた $\mathrm{X}_{1}, \mathrm{X}_{2}, \theta$ はすべて消失 


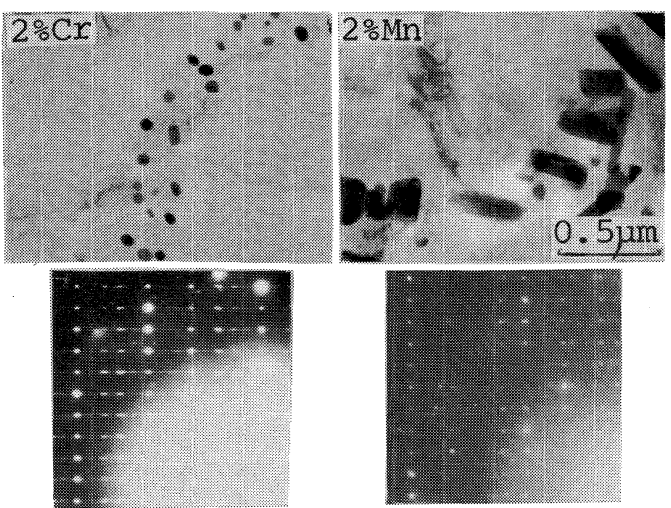

Photo 2 Transmission electron micrograph of $2 \% \mathrm{Cr}$ alloy specimen chill-cast and then homogenized as above. Micrograph of Al- $4 \% \mathrm{Cu}-$ $2 \% \mathrm{Mn}$ alloy (chill-cast and then homogenized) is referred to. Corresponding selected area diffraction patterns are also shown.

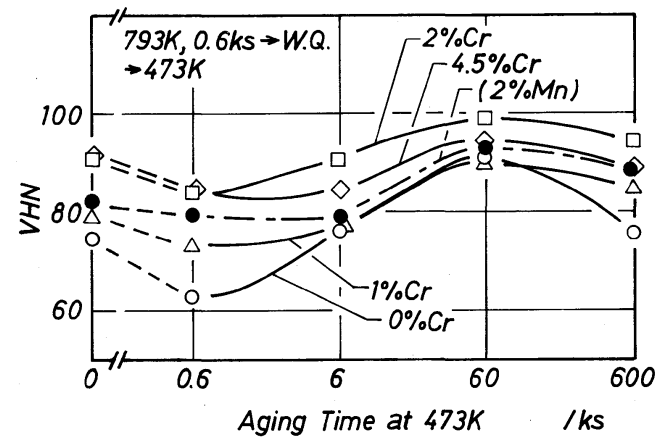

Fig. 2 Hardness vs. aging time curves of $(0 \sim$ $4.5) \% \mathrm{Cr}$ alloy specimens, homogenized, quenched into iced-water and then aged at $473 \mathrm{~K}$. Curve of $2 \% \mathrm{Mn}$ alloy $^{1)}$ is referred to.

し, $\mathrm{Cu}_{2} \mathrm{Cr}_{3} \mathrm{Al}_{20}$ 相のみが検出された。

各試片を $793 \mathrm{~K}$ で $0.6 \mathrm{ks}$ 均質化処理, 水焼入れの後, $473 \mathrm{~K}$ で等温時効した時の硬さ変化を Fig. 2 に示す。Cr 量とともに焼入れ直後の硬さは高くなるが，4.5\% Cr と $2 \% \mathrm{Cr}$ 合金の值は大差がない。各合金とも約 $60 \mathrm{ks}$ の時 効により最高硬さに達し，その值は2\% $\mathrm{Cr}$ 合金で最も優 れる。ここで $2 \% \mathrm{Cr}$ 合金と比較試料の $2 \% \mathrm{Mn}$ 合金と の差は，均質化直後の母相中の溶質濃度差（既述）に基 ゔくと思われた。

Fig. 2 において最高硬さを示した $2 \% \mathrm{Cr}$ 合金につい て473K, 60ks 時効時のTEM組織および回折図を Photo 3 に示した。 $2 \% \mathrm{Cr}$ 合金も $\mathrm{Al}-\mathrm{Cu} 2$ 元合金と同様, 板 状中間相 $\theta^{\prime}$ の析出により硬化することが分る。Cr 添加 合金は473Kの時効温度で平衡状態図的には $(\alpha+\theta+$ $\mathrm{CrAl}_{7}$ ）の 3 相合金となる ${ }^{8)}$ が，時効により $\mathrm{CrAl}_{7}$ また はこれに対応する中間相は生じず， $\theta^{\prime}$ のみを生じた（析

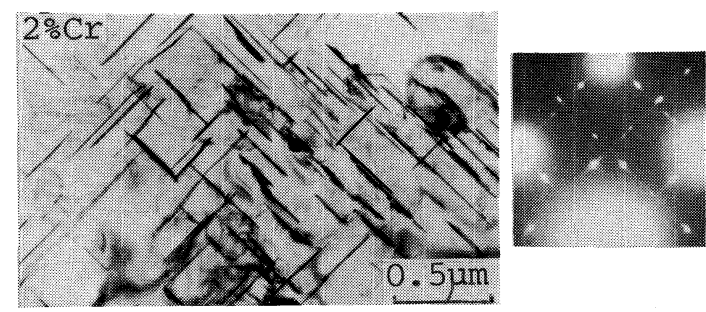

Photo 3 Bright field image and corresponding diffraction pattern of $2 \% \mathrm{Cr}$ alloy specimen aged at $473 \mathrm{~K}$ for $60 \mathrm{ks}$.

出相は均質化時に生じた $\mathrm{Cu}_{2} \mathrm{Cr}_{3} \mathrm{Al}_{20}$ と $\theta^{\prime}$ の 2 種)。理由 は $\mathrm{Mn}$ 添加合金 ${ }^{12}$ と同様， Cr 原子の拡散が著しく遅い3) ことによると思われた。

次に $473 \mathrm{~K}$ で $60 \mathrm{ks}$ 時効した $0 \sim 2 \% \mathrm{Cr}$ 合金を $623 \mathrm{~K}$ で過時効処理した時の硬さ変化を調べた。結果を実用 2219合金や $2 \% M n$ 合金のそれ とともに Fig. 3に示す が，高 $\mathrm{Cr}$ 合金ほど過時効軟化が抑えられている。そし て $2 \% \mathrm{Cr}$ では, 過時效後期（>6 ks）において2219合金 よりも軟化しにくいことが明らかであり，優れた耐熱性 を示すと思われる。2 \% Cr合金を2\% Mn 合金と比べる と，過時効初期（<6 ks）では $2 \% \mathrm{Cr}$ 合金の方が高 硬 度となるが，後期ではほぼ同程度の硬さとなる。これに 対し $548 \mathrm{~K}$ で過時効した場合は全体的に軟化速度は遅く なり，600 ks の過時効により $623 \mathrm{~K}, 6 \mathrm{ks}$ の場合と同程 度の硬さとなつた。すなわち常に $2 \% \mathrm{Cr}$ 合金の方が高 硬度となつたので， $2 \% \mathrm{Cr}$ 合金の耐熱性は $2 \% \mathrm{Mn}$ 合金 よりもやや優れると思われた。

Photo 4 には各合金を $623 \mathrm{~K}$ で $600 \mathrm{ks}$ 過時効処理した 時の組織を示す。 $0 \% \mathrm{Cr}$ 合金では $\theta^{\prime}$ が消失して粗大な $\theta$ のみの組織となり, $\mathrm{Cr}$ 添加合金では $\theta^{\prime}$ (電子線 回折 により確認) が残存し, その寸法はPhoto 3 に示した $\theta^{\prime}$ と同程度に小さい。また $\mathrm{Cr}$ 添加合金ではこれら $\theta^{\prime}$ や均質化時に生じた粗大相 ( $\mathrm{Cu}_{2} \mathrm{Cr}_{3} \mathrm{Al}_{20}$, 矢印) 以外に 微細な板状相の析出が認められ, その密度は $\mathrm{Cr}$ 量とと もに増加する。したがって Cr 添加により軟化が抑制さ れた（Fig. 3) のは， $\theta^{\prime}$ が粗大化せずに，かなり多量に 残留したのが主な原因であり，この他，母相中に依然多 くの Cr 原子が固溶している*こと,および新たに微細な 板状相が析出したことなどが関係していると思われた。 $\mathrm{Mn}$ 添加合金では多量に微細な $\mathrm{T}^{\prime}\left(\mathrm{Cu}_{2} \mathrm{Mn}_{3} \mathrm{Al}_{20}\right.$ の中間 相 $\left.^{2)}\right)$ が析出し, これによつて軟化が抑えられると解せら れた1)ので, $\mathrm{Cr}$ 添加合金は，軟化抑制機構が明らかに

* 比抵抗測定結果によると, $2 \% \mathrm{Cr}$ 合金では上記の過 時効処理後, 約 $1.2 \%$ の $\mathrm{Cr}$ が母相中に残留すると 推定された。Al-4\% Cu 合金への Cr の固溶量は623 $\mathrm{K}$ で $0.3 \%$ 以下である ${ }^{8)}$ 。 
$\mathrm{Mn}$ 添加合金のそれと異なつている。

次に Photo 4 の Cr 添加合金に見られた微細板状相に ついて EDXS 分析および電子線回折を行つた結果の例 をFig. 4 に示した。この他この析出相について 種々検 討を加えたが，これによると Mn 添加合金に生 ビた $\mathrm{T}^{\prime}$ と, 構造その他が類似する $\mathrm{Al}-\mathrm{Cu}-\mathrm{C} 3$ 元化合物 $\left(\mathrm{Cu}_{2}\right.$ $\mathrm{Cr}_{3} \mathrm{Al}_{20}$ 対応の低次中間相)であることが分つた。よつ て結果を以下に簡単に述べると，まず構造は斜方晶で $\mathrm{a}=0.333 \mathrm{~nm}, \mathrm{~b}=1.26 \mathrm{~nm}, \mathrm{c}=1.21 \mathrm{~nm}(\mathrm{Mn}$ 添加合金 ではそれぞれ 0.339，1.24，1.20 nm)；母相との方位 関係は Mn 添加合金と同様 で, $(100)_{\text {precipitate }} / /(100)_{\text {A1 }}$, $[010]_{\text {precipitate }} / /[010]_{\mathrm{Al}}$ ；さらに析出サイトおよび析出形 態については，これも Mn 添加合金と同様で, $\theta^{\prime}$ の周辺

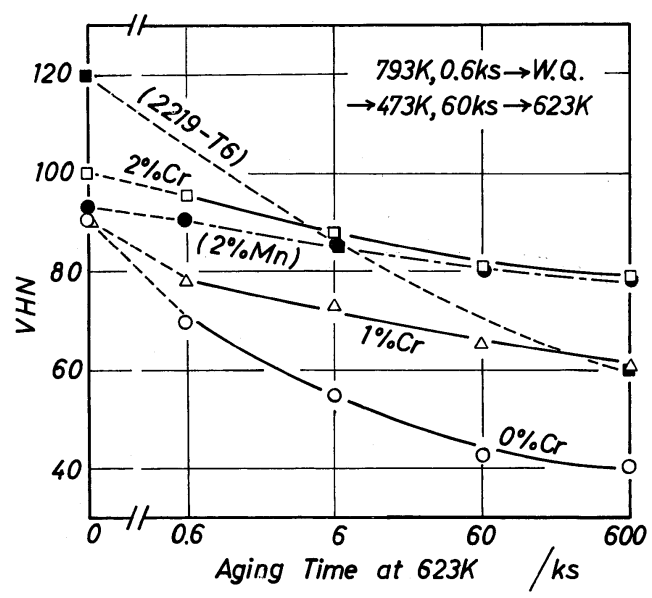

Fig. 3 Hardness vs. aging time curves obtained by over-aging at $623 \mathrm{~K}$. Specimens, aged at first at $473 \mathrm{~K}$ for $60 \mathrm{ks}$ and then over-aged. Curves of $2 \% \mathrm{Mn}$ and 2219 alloys ${ }^{1)}$, referred to.
部に不均一析出し，したがつて〈100 $\rangle_{\mathrm{A} 1}$ 方向に連なつて 見える，などが主な結果となる。異なる点は，Cr 添加 合金の場合は微細相の析出時期が， $\mathrm{Mn}$ 添加合金の $\mathrm{T}^{\prime}$ の場合に比べて著しく遅れることであり，析出時期はそ れぞれ600 ks，0.6 ks であつた。

さて Cr 添加合金では過時効処理時に $\theta^{\prime}$ が粗大化しに くく，影が長期にわたつて残留したことについて考え る。Mn を少量（約0.3\%)添加した合金においても，無 添加合金に比べれば， $\theta^{\prime}$ が安定化することはよく知られ ている ${ }^{9), 10)}$ が，その現象は $\theta^{\prime} /$ 母相間の界面に Mn 原子 が吸着し，オストワルド成長の駆動力を低下させるた め ${ }^{11)}$ とか， $\theta^{\prime}$ 中に組み込まれた Mn 原子が $\theta^{\prime}$ の外部に 拡散しにくいため ${ }^{10)}$ などとして説明されてきている。し たがつて Cr 添加合金の場合も上記のいずれかの機構に よつて $\theta^{\prime}$ が安定化されたと思われる。しかしこの場合， $\theta^{\prime}$ が著しく長期にわたつて安定化された理由はよく分ら ない。 $\mathrm{D}_{\mathrm{Cr}}$ と $\mathrm{D}_{\mathrm{Mn}}$ の差がどのようにそれに影響してい るかについてもよく分らない。今後検討が必要である。 前述の 2 つ機構のいずれをとつても界面に $\mathrm{Cr}$ や $\mathrm{Mn}$ が濃化されることになるが，そうすれば，やがて界面に そつて既述の微細板状相を生じるのは当然のこととなろ 5 。

\section{4. 結論}

チル・キャストした $\mathrm{Al}-4$ mass $\% \mathrm{Cu}-\mathrm{Cr}$ 合金につい て，その耐熱性の評価を行う目的で，主として過時効段 階における時効現象を調べ，以下の諸結果を得た。

(1) $\mathrm{Al}-4 \% \mathrm{Cu}$ 合金中に強制固溶される $\mathrm{Cr}$ 量は最大 約 $1.5 \%$ と見積もられた。鋳造後 $793 \mathrm{~K} て ゙ 0.6 \mathrm{ks}$ の均質化 処理を行うと，鋳造時に生じる $\mathrm{Cu}$ の偏析を緩和するこ
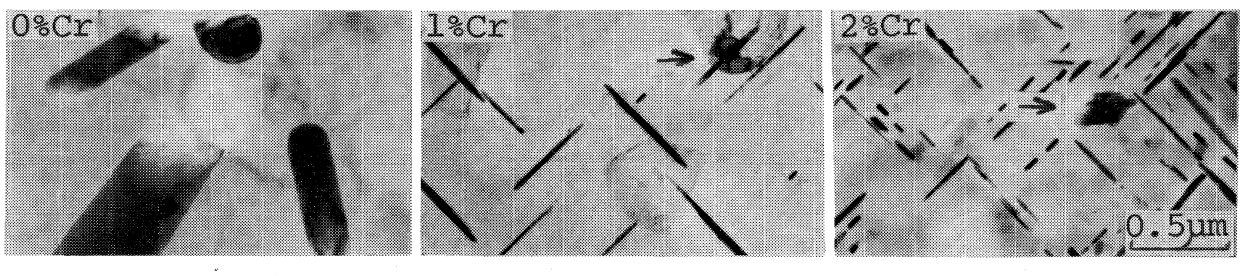

Photo 4 TEM structures of $(0 \sim 2) \% \mathrm{Cr}$ alloy specimens over-aged at $623 \mathrm{~K}$ for $600 \mathrm{ks}$.
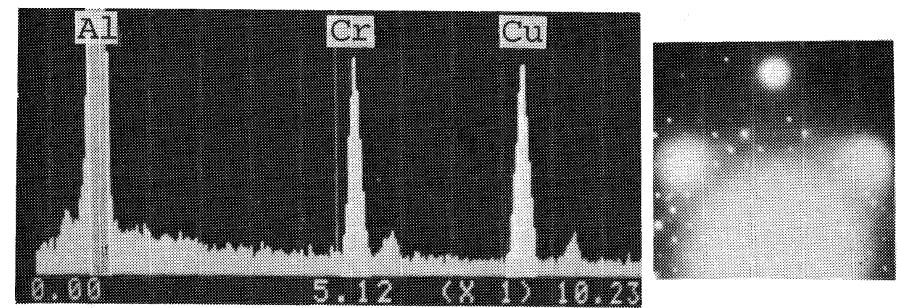

Fig. 4 Results of EDXS analysis and selected area diffraction on a fine precipitate appearing in the over-aged $2 \% \mathrm{Cr}$ alloy specimen. Refer to Photo 4. 
とができた。そしてこの処理中 $\mathrm{Cr}$ の析出量はわずかで あつた。

(2) 均質化後 $473 \mathrm{~K}$ で時効すると, $\mathrm{Cr}$ 添加合金は $\mathrm{Al}-$ $\mathrm{Cu} 2$ 元合金と同様に $\theta^{\prime}$ の析出により硬化する。このと き $0 \sim 4.5 \%$ の $\mathrm{Cr}$ 量の範囲内で， $2 \% \mathrm{Cr}$ 添加合金が最 も高硬度を示した。

(3) $473 \mathrm{~K}$ で $60 \mathrm{ks}$ 時効後, $623 \mathrm{~K}$ で過時効処理を行つ た結果， $2 \% \mathrm{Cr}$ 添加合金において最も軟化が抑えられ， その程度は2219合金よりも著しく大となつた。そして過 時効処理後の硬さは $2 \% \mathrm{Mn}$ 添加合金（チル・キャス 卜）と同程度またはそれ以上となつた。Cr 添加合金にお いて軟化が抑えられる原因は， $\theta^{\prime}$ が長期にわたつて多量 に残存し，しかもそれが粗大化しないことに主因がある と思われた。過時効処理の後期には， $\theta^{\prime}$ の界面にそつて $\mathrm{Al}-\mathrm{Cu}-\mathrm{Cr} 3$ 元系の中間相が微細に析出した。

(4) $\mathrm{Cr}$ 添加合金と Mn 添加合金とを比較すると, 強 制固溶量は $\mathrm{Cr}$ の場合の方が少なくなるが，それでも 2219合金などに比べると，優れた耐熱性を示すとみなさ れた。この他， $\mathrm{Cr}$ 添加合金と $\mathrm{Mn}$ 添加合金との過時効 組織の異同についても，これを明確にすることができ た。

\section{参 考 文 献}

1）鈴木，伊藤，小山：日 本 金属学会誌, (1983), 873.

2）跉木, 伊藤, 小山：軽金属, 34(1954), 227.

3）平野：軽金属, 29 (1979), 249.

4）村上ら：アルミニウム，(1983), No. 629， 21.

5) F. J. Kedves, H. Hondrós and L. Gergely Solid State Commun. 11 (1972), 1067.

6) W. B. Pearson: A Handbook of Lattice Spacings and Structures of Metals and Alloys, Pergamon Press, (1958), 322.

7) 長村, 中村 : 軽金属, 33 (1983), 55.

8) L. F. Mondolfo: Aluminum Alloys, Butterworths, (1976), 480.

9) V. Willig and M. von Heimendahl: $Z$. Metallk., 70 (1979), 674.

10）菅野，鈴木，叶野：軽金属，30 (1980)，684.

11) M. von Heimendahl and V. Willig: Scripta Metall., 11 (1977), 875. 